\title{
Relationship between in situ degradation kinetics and in vitro gas production fermentation using different mathematical models
}

\section{M.A.M. Rodrigues ${ }^{1}$, J.W. Cone ${ }^{2}$, C.V.M. Guedes ${ }^{1}$, L.M.M. Ferreira ${ }^{1}$}

${ }^{1}$ CECAV- Universidade de Trás-os-Montes e Alto Douro, Department of Animal Science, Apartado 1013, 5001-801 ., Vila Real, Portugal, ${ }^{2}$ Animal Nutrition Group, Department of Animal Sciences, Wageningen University, Wageningen, Netherlands

Email:mrodrigu@utad.pt

Introduction The development of alternative in vitro techniques, such as the gas production technique, has lead to the introduction of several mathematical models to describe and interpret the fermentation characteristics of feedstuffs. While there are enough data to validate each gas production model regarding its potential to estimate in situ degradation parameters, few studies have been conducted to compare models. The aim of this study was to analyse the relationship between the in situ degradation characteristics of several feedstuffs and the gas production parameters using different mathematical models.

Materials and methods Fifteen feedstuffs were evaluated. All feed samples were dried at $70^{\circ} \mathrm{C}$ and ground to pass a $1 \mathrm{~mm}$ screen before use. All samples were analysed in duplicate for ash, crude protein (CP), neutral detergent fibre (NDF), acid detergent fibre (ADF), starch and sugar. Measurements of in situ OM were performed in 3 rumen fistulated dairy cows using the nylon bag technique (Ørskov and McDonald, 1979). Residues after different incubation periods were fitted to first-order degradation in order to calculate constant rate of degradation $\left(k_{d}\right)$. Fermentable organic matter (FOM) was calculated using in situ characteristics, assuming a rumen passage rate of $6 \% \mathrm{~h}^{-1}$. Gas production incubations were performed in fully automated equipment in duplicate in a single run with rumen fluid collected from 2 non-lactating cows, $2 \mathrm{~h}$ after the morning feeding. Data were recorded every 20 minutes. Gas curves were fitted by iteration to the mono-phasic Exponential (Ørskov.and McDonald 1979), Logistic (Schofield et al., 1994), Gompertz (Lavrencic et al., 1997) and Groot (Groot et al., 1996) models. The in situ parameters were estimated from chemical and gas production variables using multiple regression analysis. Independent variables with $\mathrm{P}<0.05$ were included in the regression models.

Results CP in the feedstuffs ranged from 66 g. $\mathrm{kg}^{-1} \mathrm{DM}$ in citrus pulp to $559 \mathrm{~g} \cdot \mathrm{kg}^{-1} \mathrm{DM}$ in soybean meal, starch ranged from 2 g. $\mathrm{kg}^{-1} \mathrm{DM}$ in pressed beat pulp to 183 g. $\mathrm{kg}^{-1} \mathrm{DM}$ in maize gluten feed, sugars ranged from $2 \mathrm{~g}^{\mathrm{kg}} \mathrm{kg}^{-1} \mathrm{DM}$ in brewery grains to $272 \mathrm{~g} . \mathrm{kg}^{-1} \mathrm{DM}$ in citrus pulp and NDF ranged from $82 \mathrm{~g} \cdot \mathrm{kg}^{-1} \mathrm{DM}$ in maize to $590 \mathrm{~g} \cdot \mathrm{kg}^{-1} \mathrm{DM}$ in palm kernel expeller.

Table 1 Relationship between in situ parameters and chemical and gas production variables.

\begin{tabular}{llllll}
\hline Model & Predicted $^{1}$ & Variable $^{2}$ & $\mathrm{R}^{2}$ & $\mathrm{P}$ & RSD \\
\hline Exponential & $\mathrm{U}$ & $\mathrm{V}_{\mathrm{F}}, \mathrm{kn}, \mathrm{CP}, \mathrm{ADF}$ & 0.97 & $<0.001$ & 1.7 \\
& $\mathrm{FOM}$ & $\mathrm{V}_{\mathrm{F}}$, sugars, NDF & 0.46 & 0.0025 & 7.9 \\
\cline { 2 - 6 } Logistic & $\mathrm{U}$ & $\mathrm{V}_{\mathrm{F}}, \mathrm{CP}, \mathrm{ADF}$ & 0.94 & $<0.001$ & 2.3 \\
& $\mathrm{kd}$ & $\mathrm{Sn}, \mathrm{CP}$ & 0.79 & $<0.001$ & 1.2 \\
& $\mathrm{FOM}$ & $\mu \mathrm{m}, \mathrm{NDF}$ & 0.71 & $<0.001$ & 7.1 \\
\cline { 2 - 6 } Gompertz & $\mathrm{U}$ & $\mathrm{V}_{\mathrm{F}}, \mathrm{CP}, \mathrm{ADF}$ & 0.94 & $<0.001$ & 2.4 \\
& $\mathrm{kd}$ & $\mathrm{Cg}, \mathrm{A}, \mathrm{kn}, \mathrm{CP}$ & 0.89 & $<0.001$ & 0.9 \\
& $\mathrm{FOM}$ & $\mathrm{V}_{\mathrm{F}}, \mathrm{kn}, \mathrm{NDF}$ & 0.71 & $<0.001$ & 7.0 \\
\hline \multirow{5}{*}{ Groot } & $\mathrm{U}$ & $\mathrm{V}_{\mathrm{F}}, \mathrm{C}, \mathrm{Trmax}, \mathrm{ADF}$ & 0.92 & $<0.001$ & 2.7 \\
& $\mathrm{kd}$ & $\mathrm{B}, \mathrm{CP}$ & 0.67 & $<0.001$ & 1.5 \\
& $\mathrm{FOM}$ & $\mathrm{V}$ F, B, NDF & 0.85 & $<0.001$ & 5.1 \\
\hline
\end{tabular}

${ }^{1} \mathrm{U}$, undegradable fraction; ${ }^{2} \mathrm{~V}_{\mathrm{F}}$, maximum gas production; kn, constant rate of gas production; Sn, specific rate of gas production; $\mu \mathrm{m}$, maximum rate of gas production; $\mathrm{Cg}$, fractional rate of gas production; $\mathrm{A}$, constant factor of microbial efficiency; $\mathrm{C}$, parameter determining the shape of the curve; Trmax, time to reach maximum rate of gas production; $\mathrm{B}$, time at which $50 \%$ of $\mathrm{V}_{\mathrm{F}}$ is reached.

There was a poor relationship between in situ parameters and gas production variables with $\mathrm{R}^{2}$ varying from 0.36 to 0.65 for $k d$ estimation using the models of Groot and Logistic and from 0.42 to 0.50 for FOM estimation using the Logistic and Gompertz models. The wash out fraction (W) showed a constant relationship with starch and sugar contents $\left(\mathrm{R}^{2}=0.64\right)$. The transformation of $k d$ to its half-life value of degradation provided a slight improvement of its prediction for the model of Groot, with $\mathrm{R}^{2}$ ranging from 0.67 to 0.79 . There was an improvement of in situ parameters prediction when chemical composition of feedstuffs was used in the multiple regression analysis for all models (Table 1).

Conclusions The models showed differences in the predictive capability for some parameters. The chemical composition variables $\mathrm{CP}, \mathrm{NDF}$ and ADF seem to be important to obtain good estimations of in situ degradation characteristics.

\section{References}

Groot, J.C.J., Cone, J.W., Williams, B.A., Debersaques, F.M.A., Latinga, E.A. 1996. Animal Feed Science and Technology. 64, 77-89.

Lavrencic, A., Stefanon, B., Susmel, P. 1997. Animal Science. 64, 423-431.

Ørskov, E.R., McDonald, I. 1979. Journal of Agricultural Science, Cambridge. 92, 499-503.

Schofield, P., Pitt, R.E., Pell, A.N. 1994. Journal of Animal Science. 72, 2980-2991. 